\title{
UPF0577 Protein KIAA1324
}

National Cancer Institute

\section{Source}

National Cancer Institute. UPF0577 Protein KIAA1324. NCI Thesaurus. Code C127021.

UPF0577 protein KIAA1324 (1013 aa, 111 kDa) is encoded by the human KIAA1324

gene. This protein is involved in autophagy and binding to poly(A) RNA. 